\title{
Molecular Films*
}

$\mathrm{T}$ HE forces between molecules of organic liquids of non-ionic type are ordinarily of such short range that they act only when the molecules are in contact. The magnitude of the force depends mainly upon the area, and the nature of, the two contacting molecular surfaces. This principle of independent surface action has been a useful guide in the development of theories of surface tension phenomena and should be equally valuable for theories of vapour pressures and solubilities. It leads directly to the concept of molecules having hydrophobic and hydrophilic parts which spread as oriented monolayers on a water surface.

Such monolayers can have the properties of twodimensional gases, liquids or solids. A type of film called a duplex film, having no three-dimensional analogue, has two interfaces (an upper and a lower), which are separated by a thin three-dimensional layer (the interstratum).

Expanded films, such as monolayers of myristic acid on acidulated water, are duplex films in which the interstratum is a hydrocarbon liquid. The lower interface contains all the hydrophilic groups. These, because of thermal agitation, constitute a twodimensional gas that exerts a surface pressure, causing the expansion of the film.

Many proteins, although very soluble in water, form remarkably insoluble monolayers which are duplex films. The interstratum consists of polypeptide chains which form loose loops attached at intervals to the upper interface by hydrophobic groups. These give to the upper interface the properties of a two-dimensional gas. When the monolayer is compressed, some of the hydrophobic groups are driven from the upper interface into the inter. stratum. The irreversible formation of the mono-

* Substance of the Pilgrim Trust Lecture delivered by Dr. I. Langmuir, For. Mem. R.S., before the Royal Society on December 8 . layers indicates that the globular proteins have an entirely different structure and gives support to the cyclol theory.

The viscosities and elasticities of monolayers furnish information regarding the cross linkages between the chains.

Stearic acid spread on water containing traces of barium salts gives monolayers which can be deposited by a dipping process upon solid plates. By successive dips, any number of layers, up to 3,000 , can be built up. Optical measurements, involving interference of light reflected from the top and bottom surfaces, give accurately the thickness of the film.

Single monolayers of various substances, deposited upon barium stearate multilayers of critical thickness (about $\frac{1}{4}$ wave-length), are readily visible to the naked eye because of the change of colour. With monochromatic light the thickness of the monolayer can be measured to within about $2 \mathrm{~A}$.

The barium stearate multilayers are both hydrophobic and oleophobic (non-wettable by oil). Dipping into dilute solutions of thorium nitrate causes an overturning of the outside layer of molecules, making the surface polar and hydrophilic. Such conditioned sur. faces can absorb many organic substances from solution, giving observable increases of thickness. This technique serves as a valuable tool in biological investigations.

Free stearic acid in barium stearate multilayers can be dissolved out by dipping the film into benzene containing 1 per cent alcohol, leaving a skeleton of unchanged thickness, but of refractive index which may be as low as $1 \cdot 2$. The application of a drop of oil fills the pores of the skeleton without wetting the surface and restores the original colour. Films of many substances may be deposited upon skeleton films and the permeability of the deposited films to liquids or vapours can thus be measured optically.

\section{A Primitive Philosophy of Life*}

$\mathbf{I}^{\mathrm{T}}$ has been rather the fashion of recent years to make too light of what is known as the comparative method in anthropology, used with such effect by Sir Edward Tylor and perfected by Sir James Frazer. So much of the work Frazer has done in that field is now taken for granted, that we are perhaps too prone to forget that but for the cornparative work done by him, much of the intensive investigation into particular areas which is now possible would scarcely have begun to take place. In the present lecture, a hypothesis is put forward in regard to certain conceptions on which Sir James has had much to tell us-conceptions of life.

That conception of life which forms the subject of the lecture was first thrust on Prof. Hutton's atten-

* A Primitive Philosophy of Life. By Prof. J. H. Hutton. (The Frazer Lecture, 1938.) Pp. 24. (Oxford: Clarendon Press ; London University Press, 1938.) 28. net. tion when investigating the head-hunting practices of the Naga tribes of Assam. The Karen apparently regard the soul as leaving the body and proceeding to the underworld, where eventually it becomes a vaporous substance in a bladder or egg, which bursts, and the contents spread over the fields, fertilizing the developing flower of the rice plant and other herbs of the field. This seems to embody a conception of life as a material finite substance-a vaporous matter, limited in form and extent, and on the possession of which the propagation and renewal of life depends. It is to be noticed that this condensation of the life substance does not take place immediately after death, but the shade of the deceased continues to exist in a land of shades as a sort of separable soul, before the pupating process, which precedes the next manifestation of the psyche as a sort of fertilizer of vegetation. Clearly the belief of the Karens is not 
rudimentary but has been the subject of speculation and elaboration.

This idea of the Karens does not stand alone, but has many parallels, particularly in the Indonesian area. The notion of dew as embodying life seems to be widespread, and was not unfamiliar in Great Britain, for example, in the seventeenth century. One of the most meticulous and detailed beliefs about life-material, or 'soul-substance', is recorded among the Kai of what was formerly German New Guinea. Life-material is there identified with the shadow, the reflection and the personal name, and appears to reside in every part of the body, saliva, excreta, the glance of the eye and even the voice. This idea is not foreign to civilized ideas, for it appears in Plato's "Timæus", and is said to be found in the Taoist philosophy of China, while in the Vedanta philosophy of Hinduism, the body is the exterior of a series of sheaths encasing the soul, of which the interior less material sheaths accompany it on its migrations.

Soul material is particularly strong in certain parts of the body, particularly the head. In San Cristoval, one soul emerges from the head after death, a round stone or fossil being used as a receptacle, in which it is placed among the family gods, or, it may be, in the fertilizing waters of a river. The other part of the soul similarly goes into a sacred stone of a baetylic nature, just as the soul in so many Naga tribes enters the wooden statue on the grave, or the memorial stone erected in the rice fields. A third possible destination for the San Cristoval souls is the mandible of the deceased. Hence the mandible of a dead chief is preserved to bring luck in hunting, or to remind them of the duty of blood revenge. The importance of the lower jaw is widespread in Indonesia, and extends to Polynesia, while in West Africa the possession of the mandible gives power over the ghost.

These beliefs in the selective location of the soulsubstance in the head, and its relation to fertility, are basic in the practice of head-hunting. The Kwotto seem to state specifically that the enemy head is abstracted in order to transfer to the decapitator, or rather to his community, the virility and power of the slain, and so to build up a sort of virility-power reserve, to be drawn on as the com. munity requires.

In many instances the life material is in the blood; and Sir James Frazer mentions many instances wherein the blood of the killed is partaken of by the killer, as well as carefully avoided, because it contains the life of the dead animal. The liver, the heart, the brain, or the eye are regarded as seats of life by various races. In parts of Papua a man will choose to eat particular parts of the body to reinforce some weakness of his own; while elsewhere people stand under the platform of the deceased to absorb his qualities by anointing themselves with the putrescent fat. Cannibalism, as an act of mourning, may also arise from this same soul-substance notion, as in Australia survivors are urged to eat portions of their dead, so as not to disturb the camp with their mourning.

That life material is regarded as present in grain is indicated by the abhorrence with which the code of Manu regards the act of pounding or grinding it, while in Indonesia plants are regarded as having soul-substance similar to that of man. Many tribes plant a coconut at the birth of a child, when the soul substance of the child is bound to the tree as it grows up. Similarly in Africa, there are stories of the transference of a soul to a plantain tree by means of the placenta planted at its foot, and in India of the fertilization - pollination as it were-of women from the flower of jasmine, or by the petals of the rose tree growing from the tomb of some long-buried saint.

Human sacrifice is clearly traceable in many cases to this same belief in life as a finite substance to be transferred from one person to another, or to vegetation and livestock. Human sacrifice, it has been pointed out, seems to be particularly closely associated with agriculture. It is possible that the association between the souls of dead ancestors and the crops is to be traced to some practice of collecting wild grass seeds and leaving them by the dead as a provision for the future, and the observation of their germination and growth. It has been suggested that the practice of agriculture may have started in this way. It is therefore not inconceivable that the desire to provide for a crop of food grains may have sometimes led to the slaughter of an individual to afford a good grave.

Another aspect of the idea of life as something concrete and finite is in its separability from the body. Hence it must be conceived in some sort of form; and we find it commonly as bee, butterfly, firefly or beetle. It seems clear then that from this conception may arise a philosophy of the soul, conceived in zoomorphic or anthropomorphic shape; while its situation in various parts of the body gives rise to the idea of a multiplicity of souls. From this the way is open to the development of every form of animism, polytheism, or monotheism, to say nothing of a conception of metempsychosis and a future life. Again, from this source are likely to develop theories of nagualism and lycanthropy, at any rate of the kind found in Assam and West Africa; also the idea that the collective soul of the herd may be specially associated with a single individual, as in Indonesia one animal is the leader, or a Ficus tree in a grove is considered the chief, who takes care that the soul substance of the other trees does not vanish. So the leader of a community could be the special receptacle of the communal life material, and totemism, so often associated with the external soul, would then be traceable to the same idea. It is possible that ideas about incest, so difficult to account for, may be derived from the same idea, for exogamy is necessary to amass fertility and life from outside the community; while for kings, incestuous marriage was enjoined, whether in order to keep the tribal life pure, or as Sir James Frazer suggests, to maintain hereditary right to rule, which has been vested in the female line.

A first stage in abstraction leads to the idea of life as a force or power, mana, then, perhaps inevitably, to taboo, while one aspect of the soul substance doctrine tends directly to sympathetic magic, as action on hair, nails, spittle, etc., affects the whole, of which it formed a part.

Question arises how did this idea originate. It seems probable that limitations of language have played a part in determining ideas as to life and soul. Primitive language is very rich in concrete terms, but poor in abstract. No doubt the lack of any terms other than concrete ones, representing a similarly restricted mental imagery, has been largely responsible for the idea of life as a concrete finite element and, therefore, for the idea of soul sub. stance. 